\title{
SMEs and Electronic Commerce: The Case of Istanbul
}

\author{
Samet Kaşik ${ }^{1}$, Assist. Prof. Dr. Erkut Altindağ ${ }^{1} \&$ Assist. Prof. Dr. Volkan Öngel ${ }^{1}$ \\ ${ }^{1}$ Beykent University, Taksim, Turkey \\ Correspondence: Assist. Prof. Dr. Erkut Altindağ, Beykent Üniversitesi, Taksim KampüsüSıraselviler Cad. No: 65 \\ Taksim 34437 Beyoğlu - İstanbul, Turkey
}

Received: January 21, 2016

Accepted: February 6, 2016

Online Published: March 6, 2016

doi:10.5430/bmr.v5n1p1

URL: http://dx.doi.org/10.5430/bmr.v5n1p1

\begin{abstract}
Electronic commerce has been increasingly popular and has become a must tool for the enterprises. Since the Internet had started to be used commonly by all segments of the society, electronic commerce gained a crucial significance as a practical way for people to meet their needs. The main purpose of this study is to examine the perception of and the expectations from electronic commerce by Small- and medium-sized enterprises (SMEs) and to evaluate the effect of the obstacles to e-commerce in the innovation processes and performance. Within this study, the impact of the innovation processes and innovation data sources in the field of electronic commerce on the performance of the enterprises is analyzed. A survey comprising of 50 questions was conducted by the participation of middle and higher level managers of the SMEs in Istanbul. In total, 277 surveys were examined.

Reliability and validity of these surveys were checked via SPSS-17 and evaluated by using the methods of factor analysis, correlation analysis, and regression analysis. As a result, it has been confirmed that factors of innovation processes and innovation data sources have a meaningful relation to the performance of companies. Therefore, the importance and necessity of investing in innovation processes and data sources for increasing the company performance are verified by this study.
\end{abstract}

Keywords: Electronic Commerce, Innovation, SMEs

\section{Introduction}

The usage of modern marketing and sales techniques, e-commerce, in particular, by SMEs, is crucial. To be able to put these techniques into practice depends on the correct realization of related R\&D and innovation processes. SMEs make huge contributions to national economies in the employment, added value, sales and investment areas. The active usage of e-commerce by SMEs may have a positive impact on the presence and sustainability of the enterprises mentioned. The realization of the innovation processes related to e-commerce by SMEs is important. SMEs are the enterprises that make the biggest contribution to the national economy in the areas of employment, added value, sales, and investment. In this respect, the importance of the presence and sustainability of SMEs for a country cannot be denied. The adopting and putting e-commerce, which has gained importance over the years and has become a necessity to gain a place in the future market, into use by SMEs is necessary not just for the sustainability of SMEs, but also for national economies to be stable. In this context, it bears a huge importance for SMEs to be able to put their innovation processes related to e-commerce into practice. "The expansion of e-commerce have been found to be extremely beneficial for marketing firms (Riasi and Pourmiri, 2015; Teigland and Wasko, 2003; Zaloom, 2003), financial institutions (Chatterjee and Carl Pacini, 2002; Riasi, 2015; Zaloom, 2003), supply chains (Amiri Aghdaie et al., 2012; Riasi, 2015), and sustainable economic growth (Riasi and Amiri Aghdaie, 2013; Riasi and Pourmiri, 2016). As DeLone and McLean point that information technology and the internet have had a dramatic effect on business operations, this paper argues about how it may affect the firm performance directly and positively.

\section{Definition of E-Commerce}

E-commerce, with its most simple definition, means buying and selling products via the Internet, and the first image that comes to people's mind is the retail shopping consumers do on such websites as Amazon. However, according to Dave Chaffey, as he has mentioned in his book named E-Business and E-Commerce Management, e-commerce should not be taken only as financial transactions between enterprises and customers by the means of electronic networks. E-commerce covers all transactions between an enterprise and any third party carried out by electronic 
means. According to the definition, non-financial transactions such as information requests of the customers should be considered as part of electronic commerce as well. In his book, Chaffey has also mentioned the definitions of e-commerce given by Kalakota and Whinston (1997) for different perspectives and different areas (Chaffey 2009, $10)$ :

i. Communication perspective - transmitting information, product, and services or payments by electronic means.

ii. Business process perspective - the implementation of technology into commercial transactions and business flow automation.

iii. Service perspective - ensuring the reduction of costs while increasing the speed and quality of the service provided.

iv. Online perspective - online selling and buying of products and information.

According to World Trade Organisation (WTO), it can be characterized as the production of goods, advertisement, sales and distribution of them on the telecommunication network (World Trade Organisation 2014). Organisation for Economic Co-operation and Development (OECD) defined the e-commerce activities as carrying out the purchase of goods and services by using methods specifically designed for placing/receiving orders on computer networks (OECD 2013).

\section{Process Innovation}

In the 1990s, when the environment of intense competition and various economic pressures dominated; minor improvements made in the processes, despite being necessary, started to be insufficient. Nowadays, companies do not aim to achieve improvements at the percentage rate but at multiplied levels; they make efforts to achieve not $10 \%$ but ten-fold development. However, to be able to make essential and serious improvements in this way, new means that will enable the easier redesign of core business processes are needed. Management, functions, units and products should not be taken as a basis, but basic business processes should be taken into consideration and examined. The way to achieve major improvements in these processes is to redesign the whole processes by using available organizational resources and innovative technologies.

Although initiatives to change these processes had been expressed in such terms as "business process redesign" or "business re-engineering" before, Thomas H. Davenport found it suitable to mention these initiatives as "business process innovation." The reason for this is that the term "process innovation" covers the creation of new business strategies, the design activities of available processes and all application stages of the management of these changes in its all complex aspects.

The key objective of innovation is to increase efficiency by saving time or reducing costs. Innovation is much more successful in reducing costs than some other methods. For example, trying to cut costs by initiating an early retirement program will reduce employees' motivation and will provoke qualified employees to start looking for other jobs. Moreover, process innovation also contributes to the need for ensuring the proper management by coordinating business processes functionally dependent on each other.

In addition to the operational objectives mentioned above, many private companies use process innovation in order to improve financial performance. Reducing the cost of the processes serves this purpose directly. Besides this, as process innovation provides efficiency in many respects, it will contribute to financial improvement as an inevitable result. However, financial improvement is needed to be considered not as the primary objective of innovation but as its result.

\subsection{Innovation and Improvement}

With its simplest meaning, innovation can be defined as an introducing of innovation. The purpose of bringing innovation to a process is to provide a large-scale and radical development. Process innovation is the implementation of new restructuring to create visible changes in the process. For this, process defining is made at first looking at the process from a broad perspective. Afterward, large-scale improvements are made together with creative and radical changes. Process innovation and process improvement are the concepts that can get involved with each other but are quite different from each other. While process innovation is related to the performing a business in an new way; process improvement covers executing the same process with a certain amount of increased efficiency and effectiveness without structural changes. If process innovation provides low-rate benefits, it would not be wrong to put it in the category of process improvement. 
The differences between process innovation and process improvement can be demonstrated by some parameters. Such factors as the level of change, the starting point, the continuity of change, implementation time, the direction of change, its scope, the level of the risk it will bring and the type of change are among them.

First of all, while the level of change is quite high and radical in innovation, it is at a low rate of improvement. While improvement starts by the current process and continues its basis, the opening of an entirely clean sheet and restructuring of the process from the very beginning are needed for performing innovation. The continuity of change and implementation time are among the differences between innovation and improvement. Innovation is realized one-time and expands over a relatively long time. As improvement can be realized as short-term and one-time, continuity can be presented in the form of slight improvement processes ongoing continuously.

The direction of change and its scope are among distinguishing characteristics between two concepts. Improvement takes place in the form of induction, i.e. the efficiency increased separately in small business processes is reflected in the grand scheme of things in small proportions. However, there is a deduction in innovation. First of all, the process is considered as a whole, and the elements of the process are redesigned starting from the process in general. Therefore, while the scope of improvement is restricted to a certain function, innovation interacts with other business functions and is more comprehensive. In addition to this, the type of change and risk factor are also among relevant parameters. While improvement brings only cultural shift within the enterprise, change that will be brought by innovation will be both at the cultural and structural level. To perform improvement is a much easier and a lot less risky venture, but its yield is quite low proportionally to its risk. Innovation is the process, the completion of which is difficult, and it has a high-risk factor. However, the benefit it will provide in case of being successful is much more than its risks. Despite the fact that process improvement and process innovation are the methods different from each other, in the case of ensuring necessary coordination, the implementation of process improvement together with process innovation increases the venture's success and the quality of the process. A continuous improvement may be preferred to innovation in the sectors where there is no intense competition or in government-sponsored enterprises. However, innovation has already become a necessity in the environments with intense competition. Electronic commerce has the potential to increase sales revenues and to reduce costs significantly by the means of efficiency provided in the operation. This increase in efficiency is provided by the reduction of inventory levels, transport costs, information costs, order and delivery time.

\section{The Differences between Electronic Commerce and Traditional Commerce}

The purpose of the traditional commerce and electronic commerce is the same, to make a profit by selling products and services. However, these two types of commerce are quite different from each other regarding the methods they use in achieving their purposes. These differences are presented in a more detail in Table 1:

Table 1. Comparison of E-Commerce and Traditional Commerce

\begin{tabular}{l|l|l} 
Activity & Traditional Commerce & E-Commerce \\
\hline Product Information & Magazines, brochures & Web sites, online catalogs \\
\hline Contact Method & Regular mail, phone & E-mail \\
\hline $\begin{array}{l}\text { Product availability } \\
\text { check }\end{array}$ & Telephone, fax, letter & E-mail, website, extranet systems \\
\hline Order generating & Printed order forms & E-mail, websites \\
\hline $\begin{array}{l}\text { Production order } \\
\text { confirmation }\end{array}$ & Telephone, fax & E-mail, websites, EDI \\
\hline Invoicing & Printed invoice forms & Websites \\
\hline
\end{tabular}

Reference: Bidgoli, Hossein. 2002. Electronic Commerce: Principles and Practice. Bakersfield, California: Academic Press.

The main differences between e-commerce and traditional commerce show themselves in communication and approval processes. There are many methods for data transfer in traditional commerce. However, none of these methods cannot be faster than e-mail or other electronic-based ways of data transfer (Esat 2004, 17). While in the classic trading system, information about the desired product to be purchased is obtained from such printed materials as catalogs, magazines and samples consulting directly with a supplier firm; in electronic commerce, information is 
usually obtained via the company's website. Orders are also made, not as in traditional commerce by forms, but again using various systems on the Internet such as EDI and EFT (Dolanbay 2000, 34). Also, the days with higher trading volumes are associated with higher price volatility (Orlowski, 2015).

\subsection{Advantages of Electronic Commerce}

Electronic commerce has many advantages both regarding commercial enterprises and consumers against traditional commerce. The tools of e-commerce extensively used by many enterprises of different scales make activities together with the actors communicating peer to peer in the trading process, such as business suppliers, customers, customs offices, banks and public institutions, much more practical, provide savings in terms of time and costs. Moreover, thanks to electronic commerce, inventory status can be checked simultaneously, and it contributes to the reduction of inventory costs by stabilizing supply-demand balance (Sarısakal and Aydin 2003, 84).

In addition to this, due to the broad market and unlimited shopping opportunities offered by e-commerce, sellers can perform advertising and marketing of their products and services all over the world, they are not limited to local markets. Electronic commerce offers the opportunity of opening to new markets without taking big risks by establishing physical offices or shops. Furthermore, in electronic commerce products and services are delivered directly to the consumer via the Internet without agents; due to the transactions done in the electronic environment savings of the staff and time can be made, and thanks to all of this operating costs show a significant reduction in the rate of $40 \%-60 \%$. Thus, enterprises can increase their competitiveness in the market. In addition to this, electronic commerce has provided a much easier access to the customers' suggestions, requests, and complaints and has helped enterprises to be more successful in the field of customer relationship management by increasing customer satisfaction (Oğuztürk and Alparslan 2011, 152).

According to Poon and Swatman, the most important factor for small companies to enter electronic commerce is the future earnings expectation. They stated that this enterprise would continue as long as their expectations were met in a tangible way and divided benefits expected from electronic commerce into two, as direct and indirect. They also evaluated these two categories inside them in two subcategories, as short-term and long-term. If it is required to illustrate this with examples, saving from communication costs can be shown as an example of direct short-term benefits; marketing and business opportunities as an example of indirect short-term benefits; customer loyalty as an example of direct long-term benefits; the development of new business areas as an example of indirect long-term benefits (Fillis and Wagner 2005, 611).

When considered from the consumers' point of view, it is also possible to see many benefits of electronic commerce. Thanks to e-commerce, consumers have the chance to make the choice among thousands of products and services being offered over the Internet even without having to wander around bazaars and markets. Moreover, with the competition increasing due to electronic commerce, consumers can get products they want at much more affordable prices. Consumers gaining the possibility to examine many alternatives of the same product presented with different opportunities in the virtual environment can purchase service of a better quality (Oğuztürk and Alparslan 2011, 153).

Return of the product purchased via the Internet is fulfilled in the cases if the purchased products turn out to be not as expected or they are damaged during shipping; moreover, many websites offer the option of unconditional return for a particular period. The consumer can monitor a purchased product since the order until it reaches the address, and the purchased product can be canceled at the procurement stage. Furthermore, the indisputable sensitivity of the consumers' information security is taken into consideration, and many enterprises offer secure payment options such as SSL, SET, 3D Secure, transfer and paying at the door on e-commerce websites. Therefore, the risks of the shopping via the Internet that can be brought to the buyer are minimized. Many shopping websites provide live support service and allow buyers to ask questions that come to their mind at the stage of product selection/order (Gökgül 2014, 82-83).

\subsection{Disadvantages of Electronic Commerce}

In addition to the advantages offered by electronic commerce, there are also some disadvantages from legal and operational aspects. In his thesis titled "Electronic Commerce in Turkey and Advantages and Disadvantages It Offered to Enterprises and Consumers", Mustafa Gökgül explained the reason underlying by the problems arising from a legal perspective as follows:

"When the Internet is considered in its entirety, it has an infrastructure that does not allow control technically. Such procedures as any legal formality, application permit, approval are not in question to access the Internet, take advantages of it, use its various commercial or non-commercial facilities. In this context, there is no owner, manager, director of the Internet and, therefore, there is no responsible for it in the legal sense." (Gökgül 2014, 81) 
The situation mentioned above poses potential risks and security vulnerabilities regarding the parties of e-commerce carried out via the Internet. If it is necessary to give a few examples of the problems raised by electronic commerce in legal issues, such issues as tax policy, foreign trade policy and copyright laws are the most important among them. Electronic Commerce has a strong influence on the trade taxation and tax policy. Because there are too many gaps in tax legislation in electronic commerce, new business models emerging with the growth and development of e-commerce (digital marketplaces, online catalogs, virtual communities, paid information services, online auctions, and portals) potentially damage the implementation of local and national tax rules. Moreover, due to the increase in international trade over the Internet, similar adverse effects are also valid for trade policy. In addition to this, the protection of copyright in electronic commerce is also a very troublesome issue. As it is known, the Internet is seen as a very cost-efficient distribution channel for the information and entertainment products incompatible with copyright such as pirated books, music, and movies. Because pirated products of this kind are of the lower cost or sometimes free, their downloading via the Internet continues to spread at great speed instead of the purchasing of original products (Gökgül 2014, 80-81).

In addition to the legal loopholes mentioned above, electronic commerce may create operational disadvantages for enterprises. One of the biggest disadvantages of e-commerce in this respect is the lack of human contact with business customers. Such opportunities as assisting customers during shopping by establishing one of one communication, persuading them to purchase a product when they are undecided are not present in e-commerce (EticaretMag.com, e.t. 12.12.2014).

The consumer experience is also among the disadvantages of electronic commerce. Many consumers do not approach the idea to buy a product that they see just on the screen and cannot examine by touching it very warmly (EticaretMag.com, e.t. 12.12.2014).

In addition to the negatives mentioned above, consumers, especially in our country, are still faced with the problem of trust towards online shopping. Such factors as not being sure about the website security level and the quality of products they buy, hesitating to share their credit card numbers with a website and the absence of a real person in front of them form the basis of this mistrust (EticaretMag.com, e.t. 12.12.2014).

Such problems as the frequency of advertisement and campaign messages sent by e-mail or SMS by the enterprises after shopping over the Internet, being not able to reach customer representatives in case of problems after purchasing a product, an excessive prolongation of the product's lead time, the delivery of a wrong product become annoying especially for consumers, even if such incidents do not happen all the time.

\subsection{SMEs in the European Union}

The explicit definition of SMEs in the European Union was made by the decision taken by the EU Commission on May 6, 2003, and the criteria that would determine to characterize of enterprises as SMEs were taken into a common framework that would be valid in all EU countries. According to the decision taken, enterprises with the annual number of employees less than 250 and any of the annual revenue or financial statement not exceeding 43 million EUR is considered in the SMEs category (European Commission 2014).

Table 2. Classification of SMEs in the EU

\begin{tabular}{|c|c|c|c|c|}
\hline SME Category & $\begin{array}{l}\text { Number } \\
\text { Employees }\end{array}$ & Revenue & or & Balance Sheet \\
\hline Medium-sized & $<250$ & $\leq € 50$ million & & $\leq € 43$ million \\
\hline Small & $<50$ & $\leq € 10$ million & & $\leq € 10$ million \\
\hline Micro & $<10$ & $\leq € 2$ million & & $\leq € 2$ million \\
\hline
\end{tabular}

Reference: European Commission Official Website

(URL: http://ec.europa.eu/enterprise/policies/sme/facts-figures-analysis/sme-definition/index_en.htm 13.12.2014).

According to the statistics made just on the basis of the number of employees, the rate of the total enterprise number of SMEs in Europe in 2010 was determined as $99.8 \%$, these enterprises formed $66.9 \%$ of the European total employment, 57\% of sales revenue and 58\% of added value (Centre for Strategy and Evaluation Services 2012). 


\subsection{SMEs in the USA}

Unlike in the European Union and Turkey, there is no a general description for SMEs by the state in the United States of America (the USA). This situation originates from the comparative formation of the concepts of "small and medium-sized" and the perception change of the enterprise size depending on the sectors of the companies' activities (industry, services or agriculture). For this reason, some government agencies in the USA have made different definitions of SME for various sectors by taking the number of employees in enterprises and the annual revenue amount as criteria. The US International Trade Commission used in the SME Export Report that was published in January 2010 the SME definitions made as it is shown in Table 4 below by US Small Business Administration (SBA) and the US Department of Agriculture as criteria (Hammer 2010, 2).

\subsection{The Development and Current Situation of Electronic Commerce in Turkey}

The emergence and development of electronic commerce, which had firstly emerged in the United States of America in the 1970s, in Turkey became possible after the 1990s when the Internet started to be used in the country. Turkey that takes the $17^{\text {th }}$ place in industrialization in the world as a developing country has undergone great changes in recent years. Such developments as countries entering a customs union with the EU in 1996 and becoming a candidate to the EU in 1999 had an effect on the society and provided the increase in the investments in the information technology field (Kaynak, Tatoğlu and Kula 2005).

Due to a quite slow and expensive Internet access in the 1990s, there was no rapid growth in electronic commerce in this period. The development of e-commerce in Turkey gained speed in 1998. It was not possible to achieve the desired volumes in electronic commerce because the number of personal computers and the Internet usage rates until 2003 were far below the average in developed countries. The undeniable progress in the e-commerce transactions was recorded together with the increase in these rates (Çelik and Y1lmaz 2011).

The emergence of ADSL and fiber Internet in 2005 has become one of the breaking points regarding the sector of electronic commerce in Turkey. This allowed to start providing the Internet access in a faster and less expensive way, and this situation contributed a lot to the sector's gaining of speed (Sert 2014, 8).

According to the study of Akman and Rehan (2010), such factors as computer skills, the average daily use of the Internet are among the important factors affecting the use of electronic commerce. In the early periods of e-commerce in Turkey, the biggest reason for avoiding the use of e-commerce by consumers was determined as the issue of "payment security" at the rate of $75.93 \%$. This situation can be evaluated based on the following reasons:

$>$ The mistrust experienced regarding the question that a "virtual" seller will not be able to provide the product's warranty or the product's return opportunity,

$>$ Concerns about the delivery of the product (the delivery of damaged goods or delays/cancelations that may be experienced in the product delivery),

$>$ The doubt about the reliability of the information on the Internet,

$>$ The uneasiness created by the news regarding cyber crimes on the Internet,

$>$ The discomfort of people who are accustomed to the traditional shopping methods because they cannot see a seller personally during the Internet shopping,

$>$ Not being fully understood and spread of an electronic signature in the country (Akman and Rehan 2010, 1896).

Although the wish "to touch product", one of the typical characteristics of the buying habits of the Turkish society, had constituted a major problem for the e-commerce sector in early periods, consumer habits have changed over time due to such implementations by many internet shops as after sales support and unconditional return and this problem was able to be overcome to a large extent (Sert 2014, 7).

The issue of payment security, one of the most important obstacles emerged in front of the spread of the e-commerce sector in Turkey in the early period, was able to be eliminated to a large extent due to the ensuring of different payment methods such as transfer/paying at the door by internet shops, developments in the banking system and the increase in the level of security, and the uneasiness against shopping over the Internet decreased (Sezgin 2013).

According to the report titled "E-Commerce Sector in the World and Turkey" that was published in April 2013 by the Economic Research Division of Isbank Turkey, the number of electronic commerce websites operating in Turkey has approached 12 thousand. Although private companies constitute the vast majority of businesses operating in the electronic commerce sector, electronic sales platforms belonging to private entities such as non-governmental 
organizations and sports clubs also operate on the Internet. The structure of the existing electronic commerce market in the country is focused mostly on the e-commerce model of business-to-consumer (B2C). In recent years, in parallel with the increase in advertising and marketing activities aimed at female consumers, a fairly rapid development in the online fashion retailing has been observed in Turkey (Sezgin 2013).

According to the survey conducted by Deloitte on the issue of electronic commerce in Turkey, approximately $60 \%$ of 25 nation's leading online retailers do not have a physical store and provide service only via the e-commerce channel. This kind of companies also known as "pure player" mostly prefers to create a brand of their own (Sezgin 2013). There is a direct relationship between the number of Internet users in a country and electronic commerce. According to the report "Digital, Social and Mobile" from January 2015 prepared by internationally well-known social media agency "We are Social" and evaluating the data of 2014, the number of Internet users in Turkey in 2014 was about 37.7 million people, and this figure corresponds to $49 \%$ of total population (Kemp 2015). Again by the same report, $33 \%$ of the country's population have used electronic commerce. Furthermore, due to the rapid development of smartphones and 3G technologies in recent periods, an increase is also observed in the mobile internet use, and the rates of the mobile e-commerce use also increase in parallel with this. According to the research prepared by the social media agency 'We are Social' in January 2015, the ratio of those who purchase products or services via mobile devices in Turkey has been determined as $19 \%$ of the entire population, and as it can be seen from the following chart, Turkey takes the $7^{\text {th }}$ place among developed countries with this ratio (Kemp 2015).

The structure of the domestic market of the electronic commerce sector according to the some selected areas of activity and its volume can be seen in detail in the following Figure 1 presented in the Electronic Commerce Market Definition in Turkey and the Report of Market Size 2013 published by Informatics Industry Association (TUBISAD). According to this report, the total volume of the e-commerce market for 2013 in Turkey was recorded as 14.0 billion TL, 5.1 billion TL of this amount is formed by vacation and travel expenses, 5.0 billion TL is formed by retail shopping selling only online, and 2.3 billion TL is formed by shopping done via e-commerce websites that have multi-channel, i.e. both online and physical shops (Deloitte 2014).

\subsection{Effects of Electronic Commerce on Economic and Social Life}

Despite the fact that the purpose of gaining maximum profit with minimum costs, which is the most fundamental principle for enterprises, has remained the same, the structure of the classic trade understanding and its elements have undergone significant changes together with the emergence of electronic commerce. Electronic commerce has brought great changes in the economic field, and, therefore, this situation has had significant effects also reflecting in the social sector.

The most obvious impact of electronic commerce on the economy has been removing barriers in the area of economic activities. As a result of information technologies progressing at a great pace, the economic impacts of electronic commerce that has the potential to bring all producers, suppliers and consumers together are thought to be quite significant (Doğaner 2007, 33). Electronic commerce basically evaluated as an economic phenomenon brings changes, the impact of which on social life is undeniable, as a result of globalizing markets and the spread of the Internet in every area (Doğaner 2007, 41).

As said in "E-Commerce Report" published by the Ministry of Education within the scope of the Empowerment Project of Vocational Education and Training System (MEGEP), "According to the research carried out by OECD in the member countries in the mid of 1998 and published in 1999, it was determined that electronic commerce be the reason for considerable changes in economic and social life" (MEGEP 2007, 15).

Electronic commerce reduces the overall costs of enterprises by minimizing bureaucracy and manual transactions, costs reduced are reflected in prices, and this situation has the impact of increased competition between enterprises increasing the effect. As competition increases, the products, being the subject of preference from consumers, and company options increase, and, therefore, the market power belonging to the manufacturer in classic marketing passes to the consumer in electronic commerce. Moreover, the opportunity for continuous trading or shopping is provided in electronic commerce with 7/24 working principle, the problem of time constraint is eliminated for manufacturers, and a great convenience is provided for consumers (Uygur 2010, 44).

E-commerce brings business operations (commercial activities) closer to full competition as it is supposed to be. Thus, enterprises at all levels may have an equal chance regarding market access conditions. Thanks to this situation, the B2C rate is expected to rise, it becomes easier for SMEs to reach consumers directly at home and, therefore, to increase their competitiveness by expanding their market share (MEGEP 2007, 17). 
Electronic commerce facilitates the relationships between suppliers, manufacturers, customers and users; affects the commercial environment both on the local and international basis and ensures the creation and development of employment opportunities. In this respect, the changes brought by electronic commerce are felt mostly by SMEs. The digital environment offers an effective and inexpensive marketing channel for SMEs and in this way increases their chances to compete with large-scale enterprises (Kalayc1 2008, 148). Time and space constraints, which are among the basic elements of marketing, are eliminated by electronic commerce; the attractiveness of being close geographically to a targeted market is declining. It can be said that SMEs that have a more flexible structure than large-scale companies because of their size and, therefore, can adapt more quickly to the customer expectations are in a more advantageous position in electronic commerce (MEGEP 2007, 16). The electronic commerce use may increase company's performance directly in a positive way, just as an effective strategic human resource management, skilled personnel and intellectual capital (Husalid, 1995).

\section{Methodology and Implementation}

\subsection{Purpose of the Research}

This research study entirely serves an academic purpose; the aim of this study is to examine the perception of electronic commerce by SMEs, to determine the tendency and expectations related to e-commerce, to investigate the obstacles in front of performing electronic commerce by SMEs and their presence in e-commerce and accordingly to conduct an academic evaluation of innovation processes, performances, and information resources.

The aim of this study is to analyze the company performance of SMES conducting electronic commerce and to achieve scientifically meaningful results in the light of the data obtained by using scientific methods.

\subsection{Scope and Limitations of the Research}

In this study, in which the presence of SMEs in electronic commerce and accordingly the effects of innovations on company performance were investigated, SMEs operating in Istanbul were determined as the sample. To be able to form a good sample universe, SMEs in different areas as far as possible were reached by using various media including surveys and advertising. Taking into account that the data collection process was performed only in Istanbul while conducting this study, this research will be inadequate when compared to national and global scales. Despite of the fact that this region mentioned above is more developed economically and in terms of electronic commerce than the rest of the country, it is recommended for the academicians who will want to do a research on this subject in the future to conduct their studies in the whole country in order to be able to obtain more comprehensive and more important findings. The research carried out in a larger geographical area, and a homogeneous sample mass may bring this study to more generalizable results. Analyzes performed are based on the survey data collected from 277 participant managers from six different sectors; more accurate results and a larger picture can be obtained with a larger sample mass.

\subsection{Research Method and Model}

In the study, research data were collected using the survey method. It was aimed to form survey questions in the variety that will enable to obtain maximum information under existing conditions. Moreover, 7 -point Likert attitude scale that was thought to give more reliable results compared to 5-point and 10-point scales was used in the preparation of the questionnaire form. The example of the questionnaire form prepared in this way is presented in Appendix-1.

The options presented in the answers to the questions in the questionnaire represent the following values: (1) totally disagree, (2) mostly disagree, (3) partially disagree, (4) neither agree nor disagree, (5) partially agree, (6) mostly agree, (7) totally agree.

The questionnaire form created was published via Google.com and shared by e-mail. In addition to this, in order to provide diversity within the target group, the questionnaire form directly shared via LinkedIn.com with many employees of SMEs operating in various sectors was transmitted to the related individuals via the advertisements made with user targeting in facebook.com channel, and the data diversity was supported.

As a result, the questionnaire form created on the Internet and the sharing and distribution of which were carried out using online media were filled in by middle, and senior managers of SMEs in Istanbul and 277 questionnaires in total were evaluated. 


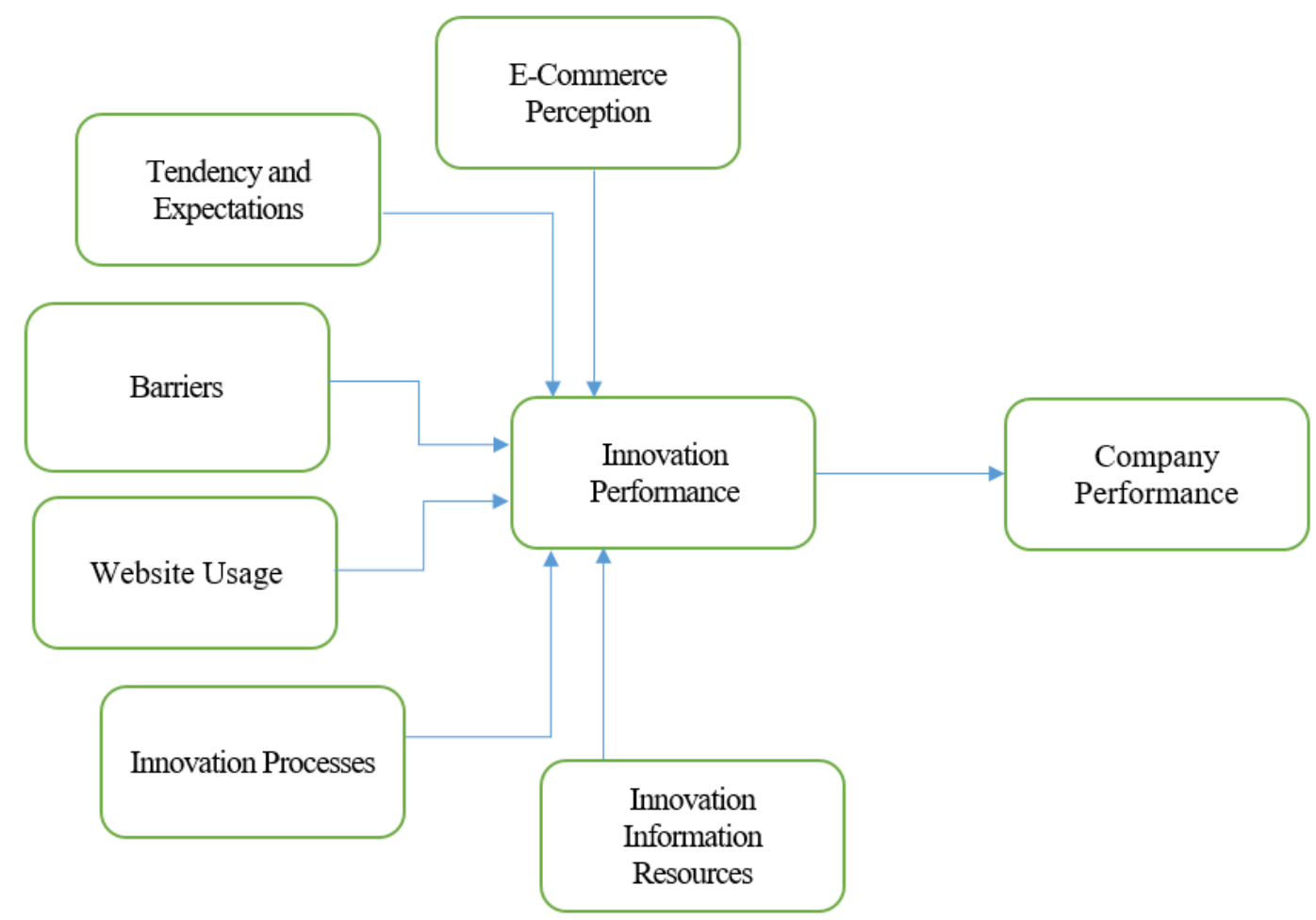

Figure 1. Research Model

\subsection{The Evaluation of Hypotheses and Data Obtained from the Research}

The scale developed for the research model was sent to 277 people in various sectors in the electronic environment, and the return from all of them was provided. The main reason for such high return rate of the questionnaire was contacting the people filling in the questionnaire form and informing them after it had been sent to them. It was observed that all questions in the questionnaire were completed, and no systematic error was made.

\subsubsection{Demographic Characteristics}

The demographic structure of the respondents is as follows:

Table 3. Percentage of the Status of the Managers Respondents

\begin{tabular}{lll}
\hline Status & Frequency & Percentage \\
\hline Senior Managers & 82 & $30 \%$ \\
Mid-Level Managers & 195 & $70 \%$ \\
TOTAL & $\mathbf{2 7 7}$ & $\mathbf{1 0 0 \%}$ \\
\hline
\end{tabular}

The distribution of the status of the managers taking part in the survey is presented in Table35. Among the respondents, 12 people (4\%) are senior managers, 54 people (18\%) are mid-level managers, 88 people (29\%) are specialists, 151 people $(50 \%)$ are authorities. A significant number of authorized employees can be explained by the age of $66 \%$ of the respondents being in the range of 26-35 years. The rate of specialists has increased to $29 \%$ because the titles of the employees in information sector are named as specialists. The percentage of senior managers has remained as $4 \%$ due to the failure to deliver the questionnaire requests to many senior managers. 
Table 4. The Distribution of the Enterprises Taking Part in the Survey by Their Operating Sectors

\begin{tabular}{lll}
\hline Operating Sector & Frequency & Rate \\
\hline Food/Beverages/Tobacco & 17 & $6 \%$ \\
Wood/Paper/Printing & 0 & $0 \%$ \\
Drugs/Medical Devices & 0 & $0 \%$ \\
Clothing/Textile/Leather & 98 & $35 \%$ \\
Banking and Finance & 45 & $16 \%$ \\
Automotive & 0 & $0 \%$ \\
Furniture & 24 & $9 \%$ \\
Chemicals/Petroleum/Tyres & 0 & $0 \%$ \\
Base Metal & 0 & $0 \%$ \\
IT & 64 & $23 \%$ \\
Telecommunications & 0 & $0 \%$ \\
Other & 29 & $11 \%$ \\
TOTAL & $\mathbf{2 7 7}$ & $\mathbf{1 0 0 \%}$
\end{tabular}

The operating sectors of the enterprises taking part in the survey are presented in Table 4. Among the enterprises taking part in the survey, 2 companies $(1 \%)$ operate in Food/Beverages/Tobacco, 4 companies (1\%) in Wood/Paper/Printing, 3 companies (1\%) in Drugs/Medical Devices, 2 companies (1\%) in Clothing/Textile/Leather, 214 companies (70\%) in Banking and Finance, 34 companies (11\%) in IT, 2 companies (1\%) in Telecommunications, and 42 companies (14\%) in other sectors. It was observed that among the respondents there are no employees in Automotive, Furniture, Chemicals/Petroleum/Tyres and Base Metal sectors.

\subsubsection{Reliability Analyzes of the Research Scale}

After having converted all questionnaires into a data set, it was subjected to the reliability analysis that is considered as the most important stage of all research techniques used in social sciences. A general reliability rate in the questionnaire consisting of 50 questions in total was determined as 0.936 . This rate is well above the threshold value of 0.700 , and it shows that the scale is reliable to its utmost. In addition to this, all independent and dependent variables in the study were examined individually, and it was seen that their average did not fall below 0.900 . This means that those who filled in the questionnaire form perceived the questions correctly and gave similar answers to similar variables (Cronbach 1951). The reliability values of the research are presented in Table 5 below.

Table 5. Reliability Analysis of Variables

\begin{tabular}{|c|c|c|c|}
\hline $\begin{array}{l}\text { Cronbach's } \\
\text { Values }\end{array}$ & Alpha $\quad(\alpha)$ & $\begin{array}{l}\text { Cronbach's Alpha }(\alpha) \text { Values } \\
\text { Dependent on Standard Variables }\end{array}$ & Number of Variables \\
\hline ,936 & & ,936 & 50 \\
\hline
\end{tabular}

The averages of the answers given by those who filled in the questionnaire form in the survey consisting of 50 questions in total were determined as 5.34. The minimum value is 3.93 , and the maximum value is 6.28 . The variance average of all these variables is 0.315 . These data show that the answers given to the questions in the survey are clustered in a particular area and, therefore, are consistent. The basic statistical information of the study is presented in Table 6. 
Table 6. Basic Statistical Information

\begin{tabular}{llllllll}
\hline & Average & Minimum & Maximum & Range & $\begin{array}{l}\text { Maximum/ } \\
\text { Minimum }\end{array}$ & Variance & $\begin{array}{l}\text { Number of } \\
\text { Variables }\end{array}$ \\
\hline $\begin{array}{l}\text { Average } \\
\text { Variables }\end{array}$ & 5,343 & 3,931 & 6,285 & 2,354 & 1,599 &, 315 & 50
\end{tabular}

Firstly, factor analyzes on the independent variables of the study were performed. The factor of the electronic commerce perception consisting of nine questions was clustered as a whole and took place in the model as a single power variable. The factor loads of the electronic commerce perception and KMO rate are specified in Table 7.

Table 7. Component Matrix

\begin{tabular}{|c|c|c|}
\hline & & Component 1 \\
\hline et1 & & ,591 \\
\hline et2 & & 676 \\
\hline et3 & & 692 \\
\hline et4 & & ,576 \\
\hline et5 & & 652 \\
\hline et6 & & ,638 \\
\hline et7 & & ,546 \\
\hline et8 & & ,732 \\
\hline et9 & & 684 \\
\hline $\begin{array}{l}\text { Kaiser-Meyer-Olkin } \\
\text { Sampling Adequacy }\end{array}$ & Measure of & ,820 \\
\hline
\end{tabular}

Because the factor of the barriers in front of electronic commerce together with the tendency and expectation factor related to electronic commerce has a simple content as some questions, it was summarized in a single Table 8 below.

Table 8. Proportional Variables

\begin{tabular}{|l|l|l|}
\hline & Base Rate & Expansion \\
\hline $\begin{array}{l}\text { Tendency and } \\
\text { Expectation 1 }\end{array}$ & 1,000 &, 841 \\
\hline $\begin{array}{l}\text { Tendency and } \\
\text { Expectation 2 }\end{array}$ & 1,000 &, 841 \\
\hline $\begin{array}{l}\text { Kaiser-Meyer-Olkin Measure } \\
\text { of Sampling Adequacy }\end{array}$ &, 500 \\
\hline
\end{tabular}

\begin{tabular}{|l|l|l|}
\hline & Base Rate & Expansion \\
\hline barrier1 & 1,000 &, 579 \\
\hline barrier2 & 1,000 &, 760 \\
\hline barrier3 & 1,000 &, 708 \\
\hline $\begin{array}{l}\text { Kaiser-Meyer-Olkin Measure } \\
\text { of Sampling Adequacy }\end{array}$ &, 665 \\
\hline
\end{tabular}

The factor of tendency and expectations related to electronic commerce consists of two questions in total, and KMO value was determined as 0.500 . The reason for this rate to remain below 0.600 , which is the base value, is the factor's consisting of only two questions. This situation was not considered as a problem within the scope of the study because in such cases the decision is taken by looking at the general reliability value including all questions and $\mathrm{KMO}$ rate.

The scale related to website use was divided into two inside itself. While the first five questions were clustered together, all matters between six and 10 were assigned to the second factor. The factor analyzes related to the scale are determined in the following table. 
Table 9. Component Matrix

\begin{tabular}{|l|l|l|}
\cline { 2 - 3 } \multicolumn{1}{c|}{} & \multicolumn{2}{l|}{ Components } \\
\cline { 2 - 3 } \multicolumn{1}{c|}{$\mathbf{1}$} & $\mathbf{2}$ \\
\hline Web1 & &, 538 \\
Web2 &, 786 \\
Web4 & &, 675 \\
Web5 &, 752 \\
Web6 &, 816 &, 719 \\
Web7 &, 785 & \\
Web8 &, 765 & \\
Web9 &, 658 & \\
Web10 &, 690 & \\
\hline Kaiser-Meyer-Olkin Measure of Sampling &, 663 \\
Adequacy & \\
\hline
\end{tabular}

The factor analysis, in which innovation process and innovation information resources take place, is described in detail in Table 10.

Table 10. Factor Analyzes of Innovation Process and Innovation Information Resources

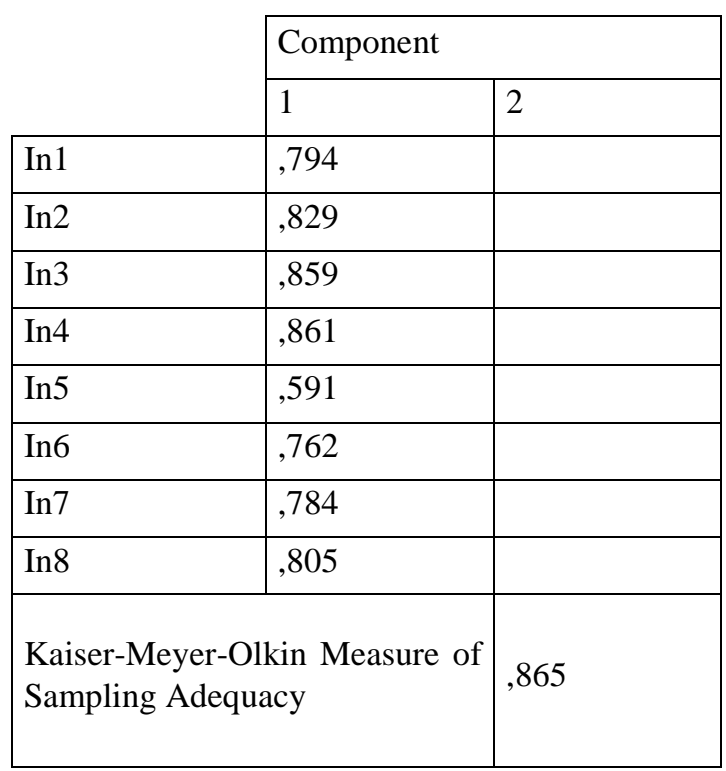

\begin{tabular}{|l|l|l|}
\cline { 2 - 3 } \multicolumn{1}{c|}{} & \multicolumn{2}{l|}{ Component } \\
\cline { 2 - 3 } \multicolumn{1}{c|}{} & 1 & \multicolumn{2}{l|}{} \\
\hline IIR1 & &, 889 \\
\hline IIR2 &, 549 &, 762 \\
\hline IIR3 &, 687 &, 868 \\
\hline IIR4 &, 756 & \\
\hline IIR5 &, 855 & \\
\hline IIR6 &, 906 & \\
\hline IIR7 &, 811 & \\
\hline IIR8 &, 836 &, 856 \\
\hline IIR9 &, 695 & \\
\hline IIR10 & & \\
\hline IIR11 & $\begin{array}{l}\text { Kaiser-Meyer-Olkin Measure of } \\
\text { Sampling Adequacy }\end{array}$ & \\
\hline
\end{tabular}

The innovation performance defined as the dependent variable of the study consists of seven questions in total, and it was observed that they were clustered under a single heading as a result of factor analyzes conducted. (See: Table 13) 
Table 11. Component Matrix

\begin{tabular}{|c|c|c|}
\hline & Component 1 & \\
\hline IP1 &, 719 & \\
\hline IP2 & ,834 & \\
\hline IP3 & ,814 & \\
\hline IP4 & ,762 & \\
\hline IP5 &, 775 & \\
\hline IP6 & ,600 & \\
\hline IP7 & ,700 & \\
\hline \multicolumn{2}{|c|}{$\begin{array}{lll}\text { Kaiser-Meyer-Olkin } & \text { Measure } & \text { of } \\
\text { Sampling Adequacy } & & \end{array}$} & ,823 \\
\hline
\end{tabular}

All statistical checks to be done before starting the correlation analysis together with the factor analysis of innovation performance were performed, and no place for doubt in scientific terms was left. The relationship between the variables will be investigated in the following chapter, and the cause and effect relationship between the concepts will be established.

The attempts to measure the relationship of all variables between each other were made in the correlation analysis conducted before starting the regression analysis. As it can be seen in Table 12 below, in which all correlation coefficients take place, the variable that has the most powerful impact on innovation performance is the innovation process used by companies. For the companies paying attention to innovation to be able to maximize their level of development, their systematic monitoring of technologies and market, exchanging ideas with customers, attempts to gain new processes for the organization while looking for innovative ideas have a positive effect on company performance. $(0,759)$ It was also proven that it influenced the performance at a similar level in both factors of innovation information resources. The company's use of information resources within its innovation activities, getting information from customers, using competitors as a point of comparison, focusing on R\&D centers and engaging in activities together with universities, research centers, and professional groups directly affect and increase the company's innovation performance. 
Table 12. Correlation Table

\begin{tabular}{|c|c|c|c|c|c|c|c|c|c|c|}
\hline & & $\begin{array}{l}\text { E-Commerce } \\
\text { Perception }\end{array}$ & $\begin{array}{l}\text { Tendency and } \\
\text { Expectations }\end{array}$ & Barriers & $\begin{array}{l}\text { Webfactor } \\
1\end{array}$ & $\begin{array}{l}\text { Webfactor } \\
2\end{array}$ & $\begin{array}{l}\text { Innovation } \\
\text { Process }\end{array}$ & $\begin{array}{l}\text { Innovation } \\
\text { Information } \\
\text { Resources } 1\end{array}$ & $\begin{array}{l}\text { Innovation } \\
\text { Information } \\
\text { Resources 2 }\end{array}$ & $\begin{array}{l}\text { Innovation } \\
\text { Performance }\end{array}$ \\
\hline \multirow{3}{*}{$\begin{array}{l}\text { E-Commerce } \\
\text { Perception }\end{array}$} & \begin{tabular}{|l} 
Pearson \\
Correlation
\end{tabular} & 1 &, $306^{* *}$ &,- 033 &, 115 &, $289^{* *}$ &, $299^{* *}$ &, 103 &, $176^{* *}$ &, $279^{* * *}$ \\
\hline & $\begin{array}{l}\text { Sig. } \\
\text { (2-tailed) }\end{array}$ & &, 000 &, 581 &, 055 &, 000 &, 000 &, 086 &, 003 &, 000 \\
\hline & $\mathrm{N}$ & 277 & 277 & 277 & 277 & 277 & 277 & 277 & 277 & 277 \\
\hline \multirow{3}{*}{$\begin{array}{l}\text { Tendency and } \\
\text { Expectations }\end{array}$} & \begin{tabular}{|l|} 
Pearson \\
Correlation
\end{tabular} &, $306^{* *}$ & 1 &, $349^{* *}$ &,- 099 &, $129^{*}$ &, $196^{* *}$ &, 014 &, $282^{* *}$ &, $257^{* * *}$ \\
\hline & $\begin{array}{l}\text { Sig. } \\
\text { (2-tailed) }\end{array}$ &, 000 & &, 000 &, 100 &, 031 &, 001 &, 822 &, 000 &, 000 \\
\hline & $\mathrm{N}$ & 277 & 277 & 277 & 277 & 277 & 277 & 277 & 277 & 277 \\
\hline \multirow{3}{*}{ Barriers } & $\begin{array}{l}\text { Pearson } \\
\text { Correlation }\end{array}$ &,- 033 &, $349^{* *}$ & 1 &, $137^{*}$ &, 074 &, $171^{* *}$ &, 067 &, $253^{* *}$ &, $121^{*}$ \\
\hline & $\begin{array}{l}\text { Sig. } \\
\text { (2-tailed) }\end{array}$ &, 581 &, 000 & &, 023 &, 217 &, 004 &, 266 &, 000 &, 044 \\
\hline & $\mathrm{N}$ & 277 & 277 & 277 & 277 & 277 & 277 & 277 & 277 & 277 \\
\hline \multirow{3}{*}{ Web Factor 1} & \begin{tabular}{|l} 
Pearson \\
Correlation
\end{tabular} &, 115 &,- 099 &, $137^{*}$ & 1 &, 016 &, 018 &,- 106 &, 112 &, 042 \\
\hline & \begin{tabular}{|l} 
Sig. \\
(2-tailed)
\end{tabular} &, 055 &, 100 &, 023 & &, 796 &, 770 &, 078 &, 064 &, 491 \\
\hline & $\mathrm{N}$ & 277 & 277 & 277 & 277 & 277 & 277 & 277 & 277 & 277 \\
\hline \multirow{3}{*}{ Web Factor 2} & $\begin{array}{l}\text { Pearson } \\
\text { Correlation }\end{array}$ &, $289^{* *}$ &, $129^{*}$ &, 074 & 016 & 1 &, $694^{* *}$ &, $634^{* *}$ &, $477^{* *}$ &, $559^{* * *}$ \\
\hline & $\begin{array}{l}\text { Sig. } \\
\text { (2-tailed) }\end{array}$ &, 000 &, 031 &, 217 &, 796 & &, 000 &, 000 &, 000 &, 000 \\
\hline & $\mathrm{N}$ & 277 & 277 & 277 & 277 & 277 & 277 & 277 & 277 & 277 \\
\hline \multirow{3}{*}{$\begin{array}{l}\text { Innovation } \\
\text { Processes }\end{array}$} & \begin{tabular}{|l} 
Pearson \\
Correlation
\end{tabular} &, $299^{* *}$ &, $196^{* *}$ &, $171^{* *}$ & 018 &, $694^{* *}$ & 1 &, $608^{* *}$ &, $706^{* *}$ &, $759^{* * *}$ \\
\hline & $\begin{array}{l}\text { Sig. } \\
\text { (2-tailed) }\end{array}$ &, 000 & ,001 &, 004 &, 770 &, 000 & &, 000 &, 000 &, 000 \\
\hline & $\mathrm{N}$ & 277 & 277 & 277 & 277 & 277 & 277 & 277 & 277 & 277 \\
\hline \multirow{3}{*}{$\begin{array}{l}\text { Innovation } \\
\text { Information } \\
\text { Resources } 1\end{array}$} & \begin{tabular}{|l} 
Pearson \\
Correlation
\end{tabular} &, 103 &, 014 &, 067 &,- 106 &, $634^{* *}$ &, $608^{* *}$ & 1 &, $442^{* *}$ &, $600^{* *}$ \\
\hline & $\begin{array}{l}\text { Sig. } \\
\text { (2-tailed) }\end{array}$ &, 086 &, 822 &, 266 & ,078 &, 000 &, 000 & &, 000 &, 000 \\
\hline & $\mathrm{N}$ & 277 & 277 & 277 & 277 & 277 & 277 & 277 & 277 & 277 \\
\hline \multirow{3}{*}{$\begin{array}{l}\text { Innovation } \\
\text { Information } \\
\text { Resources } 2\end{array}$} & \begin{tabular}{|l} 
Pearson \\
Correlation
\end{tabular} & $176^{* *}$ &, $282^{* *}$ &, $253^{* *}$ &, 112 &, $477^{* *}$ &, $706^{* *}$ &, $442^{* *}$ & 1 &, $680^{* *}$ \\
\hline & $\begin{array}{l}\text { Sig. } \\
\text { (2-tailed) }\end{array}$ &, 003 &, 000 &, 000 & ,064 &, 000 &, 000 &, 000 & &, 000 \\
\hline & $\mathrm{N}$ & 277 & 277 & 277 & 277 & 277 & 277 & 277 & 277 & 277 \\
\hline \multirow{3}{*}{$\begin{array}{l}\text { Innovation } \\
\text { Performance }\end{array}$} & $\begin{array}{l}\text { Pearson } \\
\text { Correlation }\end{array}$ &, $279^{* *}$ &, $257^{* *}$ &, $121^{*}$ &, 042 &, $559^{* *}$ &, $759^{* *}$ &, $600^{* *}$ &, $680^{* *}$ & 1 \\
\hline & $\begin{array}{l}\text { Sig. } \\
\text { (2-tailed) }\end{array}$ &, 000 &, 000 &, 044 &, 491 &, 000 &, 000 &, 000 &, 000 & \\
\hline & $\mathrm{N}$ & 277 & 277 & 277 & 277 & 277 & 277 & 277 & 277 & 277 \\
\hline
\end{tabular}

* Correlation is significant at the level of 0.05 .

** Correlation is significant at the level of 0.01 . 
When the research results were examined, it was seen that the factor of electronic commerce perception that had been expected to be in the high-level relationship had a low impact on the correlation value of 0.279 . One of the main reasons for this is that some companies still do not find electronic commerce reliable, and the problems experienced due to technical difficulties in the process keep the electronic commerce perception at a low level. Therefore, a significant relationship between company performance and this factor does not draw the attention. The regression analysis was conducted at the last stage for a more comprehensive measuring of causality relationship.

In the regression analysis, in which all independent variables are evaluated at the same time, it is clearly seen which independent variables have an effect on innovation performance. Beta values of the variables in Table 13 and determination coefficient of the model will be determinant in the table evaluation.

Table 13. Coefficients

\begin{tabular}{|c|c|c|c|c|c|c|}
\hline \multirow{2}{*}{\multicolumn{2}{|c|}{ Model }} & \multicolumn{2}{|c|}{ Standardized Coefficients } & \multirow{2}{*}{$\begin{array}{l}\text { Standardized } \\
\text { Coefficients } \\
\text { Beta }\end{array}$} & \multirow{2}{*}{$\mathrm{t}$} & \multirow{2}{*}{$\begin{array}{l}\text { Significance } \\
\text { Level }(p)\end{array}$} \\
\hline & & B & $\begin{array}{l}\text { Standard } \\
\text { Error }\end{array}$ & & & \\
\hline \multirow{9}{*}{1} & (Fixed) & 411 & ,435 & & ,945 & ,346 \\
\hline & $\begin{array}{l}\text { Ecommerce } \\
\text { perception }\end{array}$ & ,077 &, 064 & ,048 & 1,196 & ,233 \\
\hline & $\begin{array}{l}\text { Tendency and } \\
\text { Expectations }\end{array}$ &, 109 &, 038 &, 121 & 2,850 & ,005 \\
\hline & Barriers &,- 063 & ,032 &,- 079 & $-1,983$ & ,048 \\
\hline & Web Factor 1 & ,044 &, 033 &, 051 & 1,343 & , 181 \\
\hline & Web Factor 2 &,- 061 & ,064 &,- 052 &,- 960 & ,338 \\
\hline & Innovation Process & ,379 & ,057 & ,425 & 6,654 & ,000 \\
\hline & $\begin{array}{l}\text { Innovation Information } \\
\text { Resources } 1\end{array}$ &, 248 &, 047 &, 264 & 5,321 &, 000 \\
\hline & $\begin{array}{l}\text { Innovation Information } \\
\text { Resources } 2\end{array}$ &, 180 &, 036 & ,260 & 4,955 & ,000 \\
\hline
\end{tabular}

Table 14. ANOVA Variance Analysis and Research Model Summary

\begin{tabular}{|l|l|l|l|l|l|l|l|}
\hline \multicolumn{2}{|l|}{ Model } & $\begin{array}{l}\text { Sum of } \\
\text { Squares }\end{array}$ & $\begin{array}{l}\text { Degree of } \\
\text { Freedom }\end{array}$ & $\begin{array}{l}\text { Mean of } \\
\text { Squares }\end{array}$ & F & $\begin{array}{l}\text { Significance } \\
\text { Level (p) }\end{array}$ \\
\hline \multirow{2}{*}{1} & Regression & 227,050 & 8 & 28,381 & 66,825 &, $000^{\mathrm{a}}$ \\
\cline { 2 - 8 } & Residual & 113,822 & 268 &, 425 & & \\
\cline { 2 - 8 } & Total & 340,872 & 276 & & & \\
\hline \multicolumn{2}{|l|}{ Model } & $\mathrm{R}$ & $\mathrm{R}^{2}$ & Corrected $\mathrm{R}^{2}$ & $\begin{array}{l}\text { Estimated } \\
\text { Error }\end{array}$ & Standard \\
\hline 1 &, $816^{\mathrm{a}}$ &, 666 &, 656 &, 65170 & \\
\hline
\end{tabular}

When the results of the analysis are examined, the factors of the innovation processes used by companies and innovation information resources affect company performance in a direct and positive way. In addition to these variables, the tendency, and expectations of the management related to electronic commerce have a distinctive effect on the performance, albeit at a low level. $66.6 \%$ of the changes in innovation performance being a dependent variable of the research are formed by these factors. It was not possible to establish cause and effect relationship because an unexplained part of approximately $35 \%$ on the performance did not take place in this research model. Therefore, the academicians who want to work in the same field in the future can develop a model that examines which variables direct this unexplained part on the performance.

When the results of the analysis are examined again, it is seen that the barriers in front of electronic commerce take a negative beta value. The thought that e-commerce is not reliable, albeit at a micro level, the insufficiency of the state 
supporting works of electronic commerce, the fact that legal infrastructure has not been formed yet affect innovation performance in a negative way. The company's innovation performance can be affected in a positive sense thanks to the implementations by the management that considers that electronic commerce will become a necessity for companies shortly and has a strategic vision. However, the most important aspect for companies to be able to maintain innovation processes in a comfortable environment is the necessity to create an organizational structure suitable for this, employment of qualified staff, investing in R \& D centers and using of right people in the right position.

\section{Result}

All companies that want to gain a competitive advantage in a dynamic sector should invest in electronic commerce and bring all their products and services together with customers in a virtual environment. Nowadays, this is no longer an option but a necessity. Thanks to electronic commerce, the speed of doing business will increase, products will reach customers at a lower cost via the Internet, a more competitive access to world markets will become possible together with a considerable reduction of costs. Thus, companies will gain a core competitive advantage, and both sales capacity and annual turnover will increase with the dynamism brought by the Internet. If the fact that the Internet has also reduced stock and inventory costs is taken into consideration, it can be said that electronic commerce affects management performance in a direct and positive way in case it is perceived and used correctly.

To be able to use electronic commerce effectively, at first, steps to eliminate barriers in front of electronic commerce must be taken. In this context, electronic commerce should be made more reliable from investors and consumers by making improvements in such areas as the creation of a legal infrastructure for electronic commerce and the increase of money transfer security over the Internet. The removal of the barriers in front of electronic commerce will provide the increase in consumers' trust in companies; moreover, this will make the sector attractive for investors. This is of crucial importance regarding improving the performance of companies. Electronic commerce is a business area that continues to grow rapidly and is open to various novelties. Therefore, for enterprises to become successful, they should monitor sectoral innovations as well as academic studies in this area, and accordingly it is becoming a necessity for them to be included in the required innovation processes. In this regard, it is important for enterprises to work with a professional team that will monitor innovations in the field of electronic commerce and will be able to integrate these processes into company strategies.

Enterprises should give as much importance as possible to R \& D studies while conducting innovation activities. In this process, academic studies, as well as government-supported projects and similar systems used by various companies should be examined, and it must be tried to provide an optimal benefit from the innovations carried out by using information resources evaluated as the most suitable for enterprises. Innovative projects to be done in this area are of great importance regarding the value they will add to global-scale studies conducted in the field of electronic commerce as they are essential for the company's development. Consulting services to be taken from consulting companies operating in the national and international area will provide a faster and more effective way to reach the points to be reached.

The design of an effective management strategy and its implementation, monitoring by enterprises their performance on a regular basis and in this direction updating by companies their operating systems on a regular basis are of great importance regarding a positive development of company performance. Inability to keep pace with the developments nowadays, when technological developments rapidly enter our lives, will put enterprises into a disadvantageous situation regarding competition. Using of domestic and foreign resources in the innovation activities carried out will ensure a faster involvement into a process. In case, these conditions are provided it must always be kept in mind that it will be advantageous regarding competition.

In the factor of innovation information resources in the questionnaire applied within the scope of our study, it was found out that private R\&D centers, consulting companies, and universities were not used as the source of information. Taking support of academic resources and professional teams will bring more successful results in the measurement of company performance and the development of innovative projects. Conducting studies of this kind may be a preliminary step in providing a competitive advantage in national and international markets.

Difficulties Encountered and Limitations: Whether there is an effect of managers' emotional intelligence and innovative corporate culture on employees' performance was investigated with $\mathbf{3 0 5}$ managers working in the companies throughout Turkey but mostly in Istanbul. To be able to make a more comprehensive generalization, it is needed to conduct the research measurement on bigger masses. Extended data will provide assistance for comparison among countries or regions. By using time series analysis, regional or international interaction among data could be 
examined within a given interval. Reactions shown within a specific time series by the variables which are influenced by each other could be analyzed, and this would pave the way for obtaining more optimal results.

\section{References}

Akman, İbrahim, ve Mohammad Rehan. (2010). The predictive impact of socio-demographic and. Scientific Research and Essays, 5(14), 1890-1898.

Amiri Aghdaie, S. F., Seidi, M., \& Riasi, A. (2012). Identifying the Barriers to Iran's Saffron Export by Using Porter's Diamond Model. International Journal of Marketing Studies, 4(5), 129-138. http://dx.doi.org/10.5539/ijms.v4n5p129

Avrupa Komisyonu. (2014). Enterprise and Industry: What is an SME? 5 Aralık. Erişim Tarihi: Aralık 13, 2014. http://ec.europa.eu/enterprise/policies/sme/facts-figures-analysis/sme-definition/index_en.htm.

Bidgoli, Hossein. (2002). Electronic Commerce: Principles and Practice. Bakersfield, California: Academic Press.

Centre for Strategy \& Evaluation Services. (2012). Final Executive Summary: Evaluation of the SME Definition. Değerlendirme Raporu, Kent: Centre for Strategy and Evaluation Services. Erişim Tarihi: Aralık 13, 2014. http://ec.europa.eu/enterprise/policies/sme/files/studies/executive-summary-evaluation-sme-definition_en.pdf.

Chaffey, Dave. (2009). E-Business and E-Commerce Management: Strategy, Implementation, and Practice. 4th Edition. Harlow: Pearson Education Limited.

Chatterjee, D., \& Carl Pacini, V. S. (2002). The shareholder wealth and trading volume effects of information-technology infrastructure investments. Journal of Management Information Systems, 19(2), 7-42.

Cronbach, Lee J. (1951). Coefficient alpha and the internal structure of tests. Psychometrika, 16(3), 297-334. http://dx.doi.org/10.1007/BF02310555

Çelik, H. Eray, ve Veysel Yılmaz. (2011). Extending the Technology Acceptance Model for Adoption of E-Shopping by Consumers in Turkey. Journal of Electronic Commerce Research, 12(2), 152-164.

Deloitte. (2014). Türkiye'de E-Ticaret: Pazar Tanımlama ve 2013 Pazar Büyüklügü Ölçümleme Çalışması (E-Trading in Turkey: Defining the market and evaluating 2013 market growth). Araştırma Raporu, İstanbul: TÜBISAD: Bilişim Sanayicileri Derneği. Erişim Tarihi: Ocak 9, 2015. http://www2.deloitte.com/content/dam/Deloitte/tr/Documents/technology-media-telecommunications/tr-tubisad -turkiye-eticaret-pazar-buyuklugu.pdf.

Delone, W. H., \& Mclean, E. R. (2004). Measuring e-commerce success: Applying the DeLone \& McLean information systems success model. International Journal of Electronic Commerce, 9(1), 31-47.

Doğaner, Murat. (2007). Elektronik Ticaret, Türkiye'de Elektronik Ticaretin Gelişimi ve Işsletmeden Tüketiciye Elektronik Ticaret Üzerine Bir Araştırma (E-Trading, The evolution of E-Trading in Turkey and an empirical research). MSc Thesis, Konya: T.C. Selçuk Üniversitesi İşletme Anabilimdalı.

Dolanbay, Coşkun. (2000). E-Ticaret Stratejileri ve Yöntemler (E-Trading Strategies and methods).. Ankara: Meteksan Sistem Yayınları.

Esat, Demet Nimet. (2004). Elektronik Ticaret ve İşletmeler Arası Elektronik Ticaret Uygulamaları (Electronic Commerce and Electronic Business to Business Trade Practices). Yüksek Lisans Tezi. Kocaeli: T.C. Kocaeli Üniversitesi SBE, 13 Ekim.

EticaretMag.com. 2013. «Türk E-Ticaret Pazarı ve İstatistikleri. (Turkish e-trade market and its statistics» $\begin{array}{lllllll}\text { eticaretmag.com. } & 6 & \text { Şubat. } & \text { Erişim } & \text { Tarihi: } & \text { Ekim } & 28,\end{array}$ http://eticaretmag.com/turk-e-ticaret-pazari-ve-istatistikleri/.

Fillis, Ian, ve Beverly Wagner. (2005). E-business Development: An Exploratory Investigation of the Small Firm. International Small Business Journal, 23(6), 604-634. http://dx.doi.org/10.1177/0266242605057655

Gökgül, Mustafa. (2014). Türkiye'de Elektronik Ticaret ve İşletmelere, Tüketicilere Sağladığı Avantajlar, Dezavantajlar (The Electronic Commerce and Business, The advantages to consumers, Disadvantages in Turkey, ) Yüksek Lisans Tezi. İstanbul: T.C. İstanbul Kültür Üniversitesi SBE, 26 Mayıs.

Hammer, Alexander. (2010). Small and Medium-Sized Enterprises: Overview of Participation in U.S. Exports. Araştırma Raporu, Washington, DC: ABD Uluslararası Ticaret Komisyonu (USITC). Erişim Tarihi: Aralık 14, 2014. http://www.usitc.gov/publications/332/pub4125.pdf. 
Huselid, M. A. (1995). The impact of human resource management practices on turnover, productivity, and corporate financial performance. Academy of management journal, 38(3), 635-672. http://dx.doi.org/10.2307/256741

Kalayc1, Cemalettin. (2008). Elektronik Ticaret ve KOBI'lere Etkileri (Impact of Electronic Commerce on SMEs). International Journal of Economic and Administrative Studies, 1(1), 139-150.

Markoff, John. (2005). What the Dormouse Said: How the Sixties Counterculture Shaped the Personal Computer Industry. New York: Penguin Books.

Miller, D. (1983). The Correlates of Entrepreneurship in Three Types of Firms. Management Science, 29, 770-791. http://dx.doi.org/10.1287/mnsc.29.7.770

Morgan, R. M., \& Hunt, S. D. (1994). The Commitment- Trust Theory of Relationship Marketing. Journal Of Marketing, 58, 20- 35. http://dx.doi.org/10.2307/1252308

Morris, M. H., \& Paul, G.W. (1987). The Relationship Between Entrepreneurship and Marketing in Established Firms. Journal Of Business Venturing, 2, 247-259. http://dx.doi.org/10.1016/0883-9026(87)90012-7

MEGEP. (2007). Pazarlama ve Perakende E-Ticaret (Retail Marketing and E-Commerce). Ders Notları, Mesleki Eğitim ve Öğretim Sisteminin Güçlendirilmesi Projesi (MEGEP), Ankara: T.C. Milli Eğitim Bakanlığı.

OECD. (2013). Glossary of Statistical Terms: E-Commerce. OECD. 17 Ocak. Erişim Tarihi: Ekim 29, 2014. http://stats.oecd.org/glossary/detail.asp?ID=4721.

Oğuztürk, Bekir Sami, ve Ali Murat Alparslan. (2011). E-Ticaret Stratejisinde Entellektüiel Sermayenin Görünümü (E-Commerce Strategy in view of intellectual capital.) Süleyman Demirel Üniversitesi Sosyal Bilimler Enstitüsü Dergisi, 1(13), 145-168.

Orlowski, L. T. (2015). From pit to electronic trading: Impact on price volatility of US Treasury futures. Review of Financial Economics. http://dx.doi.org/10.1016/j.rfe.2015.02.001

Riasi, A. (2015). Barriers to international supply chain management in Iranian flower industry. Management Science Letters, 5(4), 363-368. http://dx.doi.org/10.5267/j.msl.2015.2.005

Riasi, A. (2015). Competitive Advantages of Shadow Banking Industry: An Analysis Using Porter Diamond Model. Business Management and Strategy, 6(2), 15-27. http://dx.doi.org/10.5296/bms.v6i2.8334

Riasi, A., \& Amiri Aghdaie, S. F. (2013). Effects of a Hypothetical Iranian Accession to the World Trade Organization on Iran's Flower Industry. Consilience: The Journal of Sustainable Development, 10(1), 99-110.

Riasi, A., \& Pourmiri, S. (2015). Effects of online marketing on Iranian ecotourism industry: Economic, sociological, and cultural aspects. Management Science Letters, 5(10), 915-926. http://dx.doi.org/10.5267/j.ms1.2015.8.005

Riasi, A., \& Pourmiri, S. (2016). Examples of Unsustainable Tourism in the Middle East. Environmental Management and Sustainable Development, 5(1), 69-85. http://dx.doi.org/10.5296/emsd.v5i1.8705

Sarısakal, M. Nusret, ve M. Ali Aydın. 2003. «E-Ticaretin Yeni Yüzü Mobil Ticaret (The new face of e-trading: Mobile Trading» Havacılık ve Uzay Teknolojileri Dergisi, 1(2), 83-90.

Sert, Sami. (2014). E-Ticaret ve Perakende Sektörüne Etkiler (Effects of E-Commerce and Retail Industry).. Yüksek Lisans Bitirme Projesi, İşletme Anabilim Dal, Sosyal Bilimler Enstitüsü, İzmir: Gediz Üniversitesi.

Teigland, R., \& Wasko, M. M. (2003). Integrating knowledge through information trading: Examining the relationship between boundary spanning communication and individual performance. Decision Sciences, 34(2), 261-286. http://dx.doi.org/10.1111/1540-5915.02341

Zaloom, C. (2003). Ambiguous Numbers: Trading Technologies and interpretation in financial Business and Management Research www.sciedupress.com/bmr 6 markets. American Ethnologist, 30(2), 258-272. http://dx.doi.org/10.1525/ae.2003.30.2.258

United Nations Economic Commission for Europe (UNECE). (2014). Part 1: Introduction - Trade - UNECE. Erișim Tarihi: Ekim

28 , 2014. http://www.unece.org/tradewelcome/areas-of-work/un-centre-for-trade-facilitation-and-e-business-uncefact/out puts/standards/unedifact/tradeedifactrules/tradeedifactrules.html.

-. 2012. Yeni Başlayanlar İçin E-ticaretin Avantaj ve Dezavantajları (The advantages and disadvantages of e-trading for beginners). 12 Eylül. Erişim Tarihi: Aralık 12, 2014. http://eticaretmag.com/yeni-baslayanlar-icin-e-ticaretin-avantaj-ve-dezavantajlari/. 